\title{
Characterization of signaling pathways coupled to melatonin receptors in gastrointestinal smooth muscle
}

\author{
Rashad Ahmed, Sunila Mahavadi, Othman Al-Shboul, Sayak Bhattacharya, John R. Grider, \\ and Karnam S. Murthy* \\ Department of Physiology and VCU Program in Enteric Neuromuscular Sciences (VPENS), \\ Medical College of Virginia Campus, Virginia Commonwealth University, Richmond, VA 23298
}

\begin{abstract}
Melatonin, a close derivative of serotonin, is involved in physiological regulation of circadian rhythms. In the gastrointestinal (GI) system, melatonin exhibits endocrine, paracrine and autocrine actions and is implicated in the regulation of GI motility. However, it is not known whether melatonin can also act directly on GI smooth muscle cells. The aim of the present study was to determine the expression of melatonin receptors in smooth muscle and identify their signaling pathways. $\mathrm{MT}_{1}$, but not $\mathrm{MT}_{2}$ receptors are expressed in freshly dispersed and cultured gastric smooth muscle cells. Melatonin selectively activated $\mathrm{G}_{\mathrm{q}}$ and stimulated phosphoinositide (PI) hydrolysis in freshly dispersed and cultured muscle cells. PI hydrolysis was blocked by the expression of $\mathrm{G}_{\mathrm{q}}$, but not $\mathrm{G}_{\mathrm{i}}$ minigene in cultured muscle cells. Melatonin also caused rapid increase in cytosolic $\mathrm{Ca}^{2+}$ as determined by epifluorescence microscopy in fura-2 loaded single smooth muscle cells, and induced rapid contraction. Melatonin-induced PI hydrolysis and contraction were blocked by a non-selective $\mathrm{MT}_{1} / \mathrm{MT}_{2}$ antagonist luzindole $(1 \mu \mathrm{M})$, but not by a selective $\mathrm{MT}_{2}$ antagonist 4P-PDOT (100 nM), and by the PLC inhibitor U73122. $\mathrm{MT}_{2}$ selective agonist IIK7 $(100 \mathrm{nM})$ had no effect on PI hydrolysis and contraction. We conclude that rabbit gastric smooth muscle cells express melatonin MT1 receptors coupled to $\mathrm{G}_{\mathrm{q}}$. Activation of these receptors causes stimulation of PI hydrolysis and increase in cytosolic $\mathrm{Ca}^{2+}$, and elicits muscle contraction.
\end{abstract}

\section{Introduction}

Melatonin (N-acetyl-5-methoxytrypatmine), a derivative of 5-hydroxytryptomin (serotonin) and an endogenous signal of darkness, is secreted by the pineal gland following a circadian rhythm and regulates diverse physiological processes [1]. Enterochromaffin (EC) cells of the gastrointestinal (GI) tract are the main source of extra-pineal melatonin and substantially contribute to the peripheral blood concentrations of melatonin [2-5]. Melatonin concentration in the GI tract is 10-100 times more than the circulating levels and nearly 400 times more than in the pineal gland [6]. The melatonin synthesizing enzyme is reportedly present in enterochromaffin cells of the intestinal mucosa where it synthesizes melatonin from its precursor, serotonin [6,7]. While pineal-produced melatonin acts mostly as an endocrine substance, extrapineal-derived melatonin functions not only as endocrine, but also

Address correspondence to: Karnam S. Murthy, Ph.D., Department of Physiology, Box 980551, Virginia Commonwealth University, Richmond, VA 23298, Phone: (804) 828 0029, skarnam@vcu.edu.

Publisher's Disclaimer: This is a PDF file of an unedited manuscript that has been accepted for publication. As a service to our customers we are providing this early version of the manuscript. The manuscript will undergo copyediting, typesetting, and review of the resulting proof before it is published in its final citable form. Please note that during the production process errors may be discovered which could affect the content, and all legal disclaimers that apply to the journal pertain. 
as autocrine or paracrine substance and regulates many GI functions such as water and ion transport, proliferation of epithelium, secretion of acid, immune system, and motility [5-10].

Two mammalian subtypes of G-protein coupled melatonin receptors have been cloned and identified, $\mathrm{MT}_{1}$, and $\mathrm{MT}_{2}$ [11-13]. While both share generally similar binding characteristics for ${ }^{125} \mathrm{I}$-melatonin, the human $\mathrm{MT}_{2}$ receptor has a lower affinity $(\mathrm{Kd}=160 \mathrm{pM})$ compared to the human $\mathrm{MT}_{1}$ receptor $(\mathrm{Kd}=20-40 \mathrm{pM})$ [14]. $\mathrm{MT}_{1}$ and $\mathrm{MT}_{2}$ receptors are expressed both singly and together in various tissues of the body $[11,14,15]$. Melatonin $\mathrm{MT}_{2}$ receptors are more restrictively expressed, being found mainly in the brain, although their presence has also been detected in the lung, cardiac, aortic and coronary tissue, myometrium and granulosa cells, immune cells, duodenum and adipocytes [14].

Administered intraperitoneally, melatonin increased intestinal myoelectrical activity. This effect was reversed by the non-selective $\mathrm{MT}_{1} / \mathrm{MT}_{2}$ receptor antagonist, luzindole, and seems to be mediated by peripheral receptors [16]. Binding to selective receptors expressed on the smooth muscles and myenteric neurons of gastrointestinal tract allows melatonin to have a significant influence on gastrointestinal motility. A study by Kasimay et al.[17] indicated that melatonin inhibit gastric motility by interacting with serotonin receptors present on the vagal afferent fibers via vago-vagal inhibitory reflexes. Storr et al. $[18,19]$ has demonstrated the expression of $\mathrm{MT}_{1}$, but not $\mathrm{MT}_{2}$ receptors using RNA isolated from the muscle layers of rat stomach and intestine. Addition of melatonin to isolated muscle strips inhibited nonaderenergic and non-cholinergic mediated relaxations, and exogenous nitric oxide (NO)mediated relaxation [19]. These results suggest that melatonin actions are mediated by inhibition of nNOS activity via $\mathrm{MT}_{1}$ receptors.

The effect of melatonin may vary in different regions of the gut depending on whether the activated receptor is present predominantly on smooth muscle cells or enteric neurons. Transmitters released from the enteric neurons, in turn, modulate the intrinsic electrical and mechanical activity of the gastrointestinal smooth muscle [7,20,21]. These studies indicate the difficulties in identifying the signaling pathways activated by melatonin in vivo and in innervated in vitro preparations. To avoid the confounding effects of neural activation by melatonin, the present study has characterized the receptors for melatonin and the signaling pathways to which these receptors are coupled in freshly dispersed and cultured smooth muscle cells of the gut. Our studies demonstrate that gastric smooth muscle cells express receptors $\left(\mathrm{MT}_{1}\right)$ for melatonin preferentially coupled to $\mathrm{G}_{\mathrm{q}}$ The receptors mediate stimulation of phosphoinositide-specific phospholipase-C $\beta$ (PI-PLC- $\beta$ ) activity and intracellular $\mathrm{Ca}^{2+}$ levels and cause muscle contraction.

\section{Materials and methods}

Melatonin was purchased from Bachem (Torrance, CA). [3H]myo-inositol were obtained from PerkinElmer Life Sciences, (Boston, MA). Polyclonal antibodies to Gai1, Gai2, Gai3, Gas, and Gaq were obtained from Santa Cruz Biotechnology (Santa Cruz, CA). Polyclonal antibodies to $\mathrm{MT}_{1}$ and $\mathrm{MT}_{2}$ were obtained from Abcam (Cambridge, MA). Western blotting, Dowex AG-1 $\times 8$ resin (100-200 mesh in formate form), chromatography material and protein assay kit, $15 \%$ Tris-HCl Ready Gels were obtained from Bio-Rad Laboratories (Hercules, CA); collagenase and soybean trypsin inhibitor were obtained from Worthington Biochemical (Freehold, NJ). 4P-PDOT was obtained from Tocris (Minneapolis, MN). IIK7 was obtained from Sigma-Aldrich (St. Louis, MO). RT- PCR primers were obtained from Integrated DNA technologies, Inc (Coralville, IA). Fura-2/AM was obtained from Molecular Probes (Carlsbad, CA). Effectene Transfection Reagent, QIAEX®II Gel extraction Kit and QIAprep®Spin Miniprep Kit were obtained from QIAGEN Sciences,(Valencia, CA); PCR reagents were obtained from Applied Biosystems, Roche (Carlsbad, CA); SuperScript ${ }^{\mathrm{TM}}$ II 
Reverse Transcriptese and TOPO TA Cloning ${ }^{\circledR}$ Kit Dual Promoter were obtained from Invitrogen (Carlsbad, CA); EcoR I was obtained from New England Bio Labs(Ipswich, MA); Dulbecco's modified Eagle's medium (DMEM) was obtained from Fisher Scientific (Pittsburgh, PA). All other chemicals were obtained from Sigma, (St. Louis, MO).

Animals were housed in the animal facility administered by the Division of Animal Resources, Virginia Commonwealth University. All experimental protocols were approved by the Institutional Animal Care and Use Committee of the Virginia Commonwealth University and all procedures were conducted in accordance with the guidelines set by this committee.

\subsection{Preparation of dispersed gastric smooth muscle cells}

Smooth muscle cells from the circular muscle layer of the rabbit stomach were isolated by sequential enzymatic digestion of muscle strips, filtration, and centrifugation as described previously $[22,23]$. The antrum was cut into thin slices using a Stadie-Riggs tissue slicer and then the slices were incubated for $30 \mathrm{~min}$ in a smooth muscle buffer at $31^{\circ} \mathrm{C}$ containing $0.1 \%$ collagenase $(300 \mathrm{U} / \mathrm{ml})$ and $0.01 \%$ soybean trypsin inhibitor $(\mathrm{w} / \mathrm{v})$. The tissue was continuously gassed with $100 \%$ oxygen during the entire isolation procedure. The partly digested tissues were washed twice with 50-ml of collagenase-free smooth muscle buffer and the muscle cells were allowed to disperse spontaneously for $30 \mathrm{~min}$ in collagenase-free medium. Cells were harvested by filtration through $500 \mu \mathrm{m}$ Nitex and centrifuged twice at $350 \times g$ for $10 \mathrm{~min}$ to eliminate broken cells and organelles. The cells were counted in a hemocytometer and it is estimated that $95 \%$ of the cells excluded trypan blue. The experiments were done within 2-3 h of cell dispersion.

For some experiments, dispersed muscle cells were resuspended in DMEM containing penicillin $(200 \mathrm{U} / \mathrm{ml})$, streptomycin $(200 \mu \mathrm{g} / \mathrm{ml})$, gentamycin $(100 \mu \mathrm{g} / \mathrm{ml})$, amphotericin B $(2.5 \mu \mathrm{g} / \mathrm{ml})$ and $10 \%$ fetal bovine serum (DMEM-10). The muscle cells were plated at a concentration of $5 \times 10^{5}$ cells $/ \mathrm{ml}$ and incubated at $37^{\circ} \mathrm{C}$ in a $\mathrm{CO}_{2}$ incubator. DMEM-10 medium was replaced every three days for 2-3 weeks until confluence was attained. The muscle cells in confluent primary cultures were trypsinized $(0.5 \mathrm{mg}$ trypsin/ml), re-plated at a concentration of $2.5 \times 10^{5} \mathrm{cells} / \mathrm{ml}$ and cultured under the same conditions. All experiments were done on cells in the first passage. Previous studies have determined the purity of cultured muscle cells with smooth muscle-specific $\gamma$-actin [24]. Cultured muscle cells were starved in serum-free medium for 24 hours before each use.

\subsection{Expression of $\mathrm{Ga}_{\mathrm{q}}$ and $\mathrm{Ga} \alpha_{\mathrm{i}}$ minigenes}

The cDNA sequences encoding the last $\mathrm{COOH}$-terminal 11 amino acids of mouse $\mathrm{Ga}_{\mathrm{q}}$ (MGLQLNLKEYNLV) and human $\mathrm{Ga}_{\mathrm{i}}$ (MGIKNNLKDCGLF) were amplified by PCR and verified by DNA sequencing as previously described [25-30]. The $5^{\prime}$-end of sense primers contained a BamHI site followed by the ribosome binding consensus sequence $\left(5^{\prime}\right.$ GCCGCCACC-3'), a methionine (ATG) start code, and a glycine (GGA) to protect the ribosome binding site during translation and the nascent peptide against proteolytic degradation. An EcoRI site was synthesized at the $5^{\prime}$-end of the antisense primers immediately after the stop codon (TGA). The purified PCR products were subcloned into the mammalian expression vector pcDNA3.1(+). The oligonucleotide sequence corresponding to the $\mathrm{COOH}$-terminal 11 amino acid residuals of $\mathrm{Ga}_{\mathrm{i}}$ in random order was synthesized and ligated into pcDNA3.1(+) as a control minigene. All Ga minigene constructs used for transfection experiments were purified with an endotoxin-free maxiprep kit (Qiagen) following the manufacturing protocol. 


\subsection{Expression of $M_{1}$ in smooth muscle cells measured by RT-PCR and western blot}

Total RNA was isolated from smooth muscle cells with TRIzol® reagent (Invitrogen) and treated with TURBO DNase (Ambion). RNA from each preparation was reversely transcribed using the SuperScript ${ }^{\mathrm{TM}}$ II system containing $50 \mathrm{mM}$ Tris-HCl (pH 8.3), $75 \mathrm{mM}$ $\mathrm{KCl}, 3 \mathrm{mM} \mathrm{MgCl}, 10 \mathrm{mM}$ dithiothreitol (DTT), $0.5 \mathrm{mM}$ deoxynucleoside triphosphates (dNTP), $2.5 \mu \mathrm{M}$ random hexamers and 200 units of reverse transcriptase in a $20 \mu 1$ reaction volume. The reactions were carried out at room temperature for $10 \mathrm{~min}$ and at $42^{\circ} \mathrm{C}$ for 50 min, and terminated by heating at $70^{\circ} \mathrm{C}$ for $15 \mathrm{~min}$. Three $\mu \mathrm{l}$ of the reversely transcribed cDNA was amplified in a final volume of $50 \mu \mathrm{l}$ by PCR in standard conditions $(2 \mathrm{mM}$ $\mathrm{MgCl}_{2}, 200 \mu \mathrm{M}$ dNTP, 2.5 units Taq polymerase) with specific primers for $\mathrm{MT}_{1}$ designed based on sequence in rabbit and $\mathrm{MT}_{2}$ based on the conserved sequence in human, rat and mouse cDNAs:

\section{$\mathrm{MT}_{1}$ :}

Forward: 5'GATCCAAGGGTCTATTCCTG-3'

Reverse: 5'CCTGAAGTCCTGTGGTTTC-3'

$\mathrm{MT}_{2}$ :

Forward: 5'GTGCTCAGGAACCGCAAGC-3'

Reverse: 5'GTCTGGATGAAGGTGCAGGAA-3'

PCR for $\mathrm{MT}_{1}$ and $\mathrm{MT}_{2}$ receptors was performed for 30 cycles. For each experiment, a parallel control without reverse transcriptase was processed. The amplified PCR products were analyzed on $1.5 \%$ agarose gel containing $0.1 \mu \mathrm{g} / \mathrm{ml}$ ethidium bromide [24].

Muscle cells were solubilized in Triton X-100-based lysis buffer plus protease and phosphatase inhibitors $(100 \mu \mathrm{g} / \mathrm{ml}$ PMSF, $10 \mu \mathrm{g} / \mathrm{ml}$ aprotinin, $10 \mu \mathrm{g} / \mathrm{ml}$ leupeptin, $30 \mathrm{mM}$ sodium fluoride and $3 \mathrm{mM}$ sodium vanadate). After centrifugation of the lysates at $20000 \times$ $g$ for $10 \mathrm{~min}$ at $4{ }^{\circ} \mathrm{C}$, the protein concentrations of the supernatant were determined with a Dc protein assay kit from Bio-Rad. Equal amounts of protein were fractionated by SDS/ PAGE, and transferred onto nitrocellulose membrane. Blots were blocked in 5\% (w/v) nonfat dried milk/TBS-T [trisbuffered saline (pH 7.6) plus 0.1\% Tween-20] for $1 \mathrm{~h}$ and then incubated overnight at $4{ }^{\circ} \mathrm{C}$ with $\mathrm{MT}_{1}$ or $\mathrm{MT}_{2}$ receptor primary antibodies (1:1000) in TBS$\mathrm{T}$ plus $1 \%(\mathrm{w} / \mathrm{v})$ non-fat dried milk. After incubation for $1 \mathrm{~h}$ with horseradish-peroxidaseconjugated corresponding secondary antibody $(1: 2000 ; 10 \mu \mathrm{g} / \mathrm{ml}$, Pierce) in TBS-T plus $1 \%$ $(\mathrm{w} / \mathrm{v})$ non-fat dried milk, immunoreactive proteins were visualized using SuperSignal Femto maximum sensitivity substrate kit (Pierce). All washing steps were performed with TBS-T. The protein bands were identified by enhanced chemiluminescence reagent [28-30].

\subsection{Identification of $G$ proteins activated by melatonin}

$\mathrm{G}$ proteins selectively activated by melatonin was identified from the increase in $\mathrm{Ga}$ binding to the $\left[{ }^{35} \mathrm{~S}\right] \mathrm{GTP} \gamma \mathrm{S}$ (5'-O-3-thiotriphosphate) as described previously [28-30]. Ten $\mathrm{ml}$ of muscle cell suspension $\left(3 \times 10^{6}\right.$ cells $\left./ \mathrm{ml}\right)$ were homogenized in $20 \mathrm{mM}$ HEPES medium $(\mathrm{pH}$ 7.4) containing $2 \mathrm{mM} \mathrm{MgCl}_{2}, 1 \mathrm{mM}$ EDTA and $2 \mathrm{mM}$ DTT. After centrifugation at 30,000 $\mathrm{g}$ for $15 \mathrm{~min}$, the crude membranes were solubilized for $60 \mathrm{~min}$ at $4{ }^{\circ} \mathrm{C}$ in $20 \mathrm{mM}$ HEPES medium (pH 7.4) containing 2 mM EDTA, $240 \mathrm{mM} \mathrm{NaCl}, 0.5 \%$ CHAPS (3-[(3cholamidopropyl) dimethylammonio]-1-pro-panesulfonate), $2 \mathrm{mM}$ PMSF, $20 \mu \mathrm{g} / \mathrm{ml}$ aprotinin, and $20 \mu \mathrm{M}$ leupetin. The membrane were incubated for $20 \mathrm{~min}$ at $37^{\circ} \mathrm{C}$ with 60 $\mathrm{nM}\left[{ }^{35} \mathrm{~S}\right] \mathrm{GTP} \gamma \mathrm{S}$ in the presence or absence of melatonin $(1 \mu \mathrm{M})$ in a solution containing 10 $\mathrm{mM}$ HEPES ( $\mathrm{pH}$ 7.4), $100 \mu \mathrm{M}$ EDTA and $10 \mathrm{mM} \mathrm{MgCl}_{2}$. The reaction was terminated with 10 volumes of $100 \mathrm{mM}$ of Tris- $\mathrm{HCl}$ medium ( $\mathrm{pH} \mathrm{8.0)}$ containing $10 \mathrm{mM} \mathrm{MgCl}_{2}, 10 \mathrm{mM}$ $\mathrm{NaCl}$ and $10 \mu \mathrm{M}$ GTP, and the mixture was placed in wells precoated with specific 
antibodies to $\mathrm{Ga}_{\mathrm{q}}, \mathrm{Ga}_{\mathrm{i} 1}, \mathrm{Ga}_{\mathrm{i} 2}, \mathrm{Ga}_{\mathrm{i} 3}$, and $\mathrm{Ga}_{\mathrm{s}}$. Coating with $\mathrm{G}$ protein antibodies (1:1000) was done after the wells were first coated with anti-rabbit $\operatorname{IgG}(1: 1000)$ for $2 \mathrm{~h}$ on ice. After incubation for $2 \mathrm{~h}$ on ice, the wells were washed three times with phosphate buffer saline solution (PBS) containing $0.05 \%$ Tween-20 and the radioactivity from each well was counted by liquid scintillation. The amount of $\left[{ }^{35} \mathrm{~S}\right] \mathrm{GTP} \gamma \mathrm{S}$ bound to the activated $\mathrm{Ga}$ subunit was expressed as counts per minute (cpm) per milligram of protein.

\subsection{Phosphoinositide(PI)-specific phospholipase C (PLC- $\beta$ ) activity}

PI hydrolysis (PLC- $\beta$ activity) was determined in freshly dispersed or cultured smooth muscle cells by measuring the formation of inositol phosphates using ion-exchange chromatography as previously described $[22,23]$. Ten ml of cell suspension $\left(2 \times 10^{6}\right.$ cells/ $\mathrm{ml})$ were labeled with myo- $\left[{ }^{3} \mathrm{H}\right]$ inositol $(15 \mu \mathrm{Ci} / \mathrm{ml})$ for $90 \mathrm{~min}$ at $31{ }^{\circ} \mathrm{C}$. Then cells were centrifuged at $350 \times \mathrm{g}$ for $10 \mathrm{~min}$ to remove excess $\left[{ }^{3} \mathrm{H}\right]$ inositol and resuspended in $10 \mathrm{ml}$ of fresh medium. Lithium was added to a final concentration of $10 \mathrm{mM}$ and the suspension was incubated for $10 \mathrm{~min}$ followed by melatonin $(1 \mathrm{pM}$ to $10 \mu \mathrm{M})$ or $\mathrm{MT}_{2}$ receptor selective agonist IIK7 $(100 \mathrm{nM})$ for $60 \mathrm{~s}$. In some experiments cells were treated with melatonin in the presence and absence of a non-selective $\mathrm{MT}_{1} / \mathrm{MT}_{2}$ receptor antagonist luzindole (100 $\mathrm{mM})$, a selective $\mathrm{MT}_{2}$ receptor antagonist 4P-PDOT, PLC $\beta$ inhibitor U73122 $(10 \mu \mathrm{M})$ or MLCK inhibitor ML-9 $(1 \mu \mathrm{M})$ for $60 \mathrm{~s}$ [31-33]. Cultured smooth muscle cells were labeled with $\left[{ }^{3} \mathrm{H}\right]$ myo-inositol $(0.5 \mu \mathrm{Ci} / \mathrm{ml})$ for $24 \mathrm{~h}$ in inositol-free DMEM medium. The cultures were washed with phosphate-buffered saline (PBS) and treated with melatonin $(1 \mu \mathrm{M})$ for 1 min in HEPES medium ( $\mathrm{pH}$ 7.4). The reaction was terminated by the addition of chloroform methanol:HCl $(50: 100: 1 \mathrm{v} / \mathrm{v} / \mathrm{v})$. After chloroform $(310 \mu \mathrm{l})$ and water $(310 \mu \mathrm{l})$ were added, the samples were vortexed and the phases were separated by centrifugation at $1000 \mathrm{~g}$ for 15 $\min$. The upper aqueous phase was applied to a column containing $1 \mathrm{ml}$ of 1:1 slurry of Dowex AG- $1 \times 8$ resin (100-200 mesh in formate form) and distilled water. The column was washed with $10 \mathrm{ml}$ of water followed by $10 \mathrm{ml}$ of $5 \mathrm{mM}$ sodium tetraborate- $60 \mathrm{mM}$ ammonium formate to remove $\left[{ }^{3} \mathrm{H}\right]$ glycerophosphoinositol. Total inositol phosphates were eluted with $6 \mathrm{ml}$ of $0.8 \mathrm{M}$ ammonium formate- $0.1 \mathrm{M}$ formic acid. The eluates were collected into scintillation vials and counted in gel phase after addition of $10 \mathrm{ml}$ of scintillant. The results were expressed as counts per minute per mg protein.

\subsection{Measurement of $\mathrm{Ca}^{2+}$ release}

Melatonin-induced increase in $\left[\mathrm{Ca}^{2+}\right]_{\mathrm{i}}$ was measured by fluorescence in single smooth muscle cell loaded with fluorescent $\mathrm{Ca}^{2+}$ dye fura 2 [30]. Dispersed muscle cells were plated on coverslips for $12 \mathrm{~h}$ in DMEM. After being washed with PBS, the cells were loaded with 5 $\mu \mathrm{M}$ fura 2 -AM for $1 \mathrm{~h}$ at room temperature. The cells were visualized through a $40 \times$ objective (ZEISS; 0.9 NA) with a Zeiss Axioskop 2 plus upright fluorescence microscope and imaged with a setup consisting of a charge coupled device camera (Imago, TILL Photonics, Applied Scientific Instrumentation, Eugene, OR) attached to an image intensifier. The cells were alternately excited at 380 and $340 \mathrm{~nm}$. The background and autofluorescence were corrected from images of a cell without the fura 2. Results are expressed as increase in $340 / 380$ ratio.

\subsection{Measurement of contraction in dispersed smooth muscle cells}

Contraction in freshly dispersed gastric circular smooth muscle cells was determined by scanning micrometry as previously described [28-30]. An aliquot $(0.4 \mathrm{ml})$ of cells containing approximately $10^{4}$ cells $/ \mathrm{ml}$ was treated with melatonin $(1 \mathrm{pM}$ to $10 \mu \mathrm{M})$ or $\mathrm{MT}_{2}$ receptor selective agonist IIK7 $(100 \mathrm{nM})$ for $30 \mathrm{~s}$ and the reaction was terminated with $1 \%$ acrolein at a final concentration of $0.1 \%$. In some experiments cells were treated with melatonin in the presence and absence of the non-selective $\mathrm{MT}_{1} / \mathrm{MT}_{2}$ receptor antagonist luzindole $(100 \mathrm{mM})$, a selective $\mathrm{MT}_{2}$ receptor antagonist 4P-PDOT, PLC $\beta$ inhibitor 
U73122 $(10 \mu \mathrm{M})$ or MLCK inhibitor ML-9 $(1 \mu \mathrm{M})$ for $30 \mathrm{~s}$. The resting cell length was determined in control experiments in which muscle cells were incubated with $100 \mu \mathrm{l}$ of $0.1 \%$ bovine serum albumin without the agonists. The mean length of 50 muscle cells treated with various agonists was measured by scanning micrometry and compared with the mean length of untreated cells. The contractile response was expressed as the percent decrease in mean cell length from control cell length.

\subsection{Statistical analysis}

The results were expressed as means \pm S.E. of $n$ experiments and analyzed for statistical significance using Student's $t$-test for paired and unpaired values. Each experiment was done on cells obtained from different animals. Differences among multiple groups were tested by using ANOVA and checked for significance using Fisher's protected least significant difference test. A probability of $\mathrm{P}<0.05$ was considered significant.

\section{Results}

\subsection{Expression of MT1 in gastric smooth muscle}

Specific primers for $\mathrm{MT}_{1}$ and $\mathrm{MT}_{2}$ were designed based on the conserved sequences in human and rat cDNAs. $\mathrm{MT}_{1}$, but not $\mathrm{MT}_{2}$ receptors were detected by RT-PCR on RNA extracted from cultures of gastric smooth muscle cells in first passage. PCR product of the expected size (194 bp) was obtained for $\mathrm{MT}_{1}$ (Fig. 1A). The isolated partial nucleotide sequence of rabbit $\mathrm{MT}_{1}$ was similar to the corresponding amino acid sequences of human $(86 \%)$ and rat (83\%). mRNA expression of $\mathrm{MT}_{1}\left(194 \mathrm{bp}\right.$ ) and $\mathrm{MT}_{2}$ (392 bp) receptors was identified on RNA extracted from rabbit brain (Fig. 1). As shown previously, the use of confluent cultures of smooth muscle in first passage ensured the absence of neural, endothelial, or interstitial cell contaminants and the presence of PCR product in cultured muscle cells demonstrate the expression of $\mathrm{MT}_{1}$ mRNA in smooth muscle cells. Expression of $\mathrm{MT}_{1}$ and $\mathrm{MT}_{2}$ receptor protein was examined by western blot analysis using selective antibody to $\mathrm{MT}_{1}$ or $\mathrm{MT}_{2}$. The results demonstrate the expression of $\mathrm{MT}_{1}$ of predicted size $(\sim 40 \mathrm{kDa})$ in the homogenates of isolated smooth muscle cells. Expression of $\mathrm{MT}_{2}$ was not detected in the homogenates of dispersed gastric muscle cells (Fig. 1B). Expression of both $\mathrm{MT}_{1}$ and $\mathrm{MT}_{2}$ receptors was detected in the homogenates of rabbit brain (Fig. 1B)

\subsection{Identification of $G$ proteins coupled to $M_{1}$ receptors}

Studies in various tissues and cell lines suggest that $\mathrm{MT}_{1}$ receptors are coupled to activation of $\mathrm{G}$ proteins, but the specific $\mathrm{G}$ proteins coupled to $\mathrm{MT}_{1}$ receptors in smooth muscle has not been identified. Muscle cells membranes were incubated with $\left[{ }^{35} \mathrm{~S}\right] \mathrm{GTP} \gamma \mathrm{S}(60 \mathrm{nM})$ in the presence or absence of melatonin $(1 \mu \mathrm{M})$ and the aliquots were added to wells precoated with different $\mathrm{Ga}$ antibodies; an increase in the binding of $\left[{ }^{35} \mathrm{~S}\right] \mathrm{GTP} \gamma \mathrm{S}$ complexes to a specific $\mathrm{Ga}$ antibody reflected the activation of the corresponding $\mathrm{G}$ protein. In some experiments low concentrations of GTP $\gamma \mathrm{S}$ stimulated binding of $\left[{ }^{35} \mathrm{~S}\right] \mathrm{GTP} \gamma \mathrm{S}$ to $\mathrm{Ga}_{\mathrm{i} 2}, \mathrm{Ga}_{\mathrm{q}}$ and $\mathrm{Ga}_{\mathrm{s}}$. However, incubation of muscle membranes with melatonin in the presence of low concentrations of GTP $\gamma \mathrm{S}$ caused a significant increase in the binding of $\left[{ }^{35} \mathrm{~S}\right] \mathrm{GTP} \gamma_{\mathrm{S}}$ selectively to $\mathrm{Ga}_{\mathrm{q}}(392+45 \%$ increase above basal levels, $\mathrm{p}<0.001, \mathrm{n}=8)$, but not to $\mathrm{Ga}_{\mathrm{i} 1}$, $\mathrm{Ga}_{\mathrm{i} 2}, \mathrm{Ga}_{3}$, or $\mathrm{Ga}_{\mathrm{s}}$. These results suggest that $\mathrm{MT}_{1}$ receptors are preferentially coupled to activation of $\mathrm{G}_{\mathrm{q}}$ in gastric smooth muscle (Fig. 2B).

\subsection{Signaling pathways activated by $\mathbf{M T}_{1}$ in gastric smooth muscle}

Previous studies in smooth muscle have shown that activation of $\mathrm{G}_{\mathrm{q}}$ by excitatory neurotransmitters such as acetylcholine and substance $P$ results in the stimulation of phosphoinositide (PI)-specific phospholipase C (PLC- $\beta$ ) activity, generation of inositiol 1,4,5-trisphosphate $\left(\mathrm{IP}_{3}\right)$ and $\mathrm{IP}_{3}$-dependent $\mathrm{Ca}^{2+}$ release leading to smooth muscle 
contraction. The effector enzyme stimulated by $\mathrm{G}_{\mathrm{q}}$ proteins coupled to $\mathrm{MT}_{1}$ receptors was examined by measurements of inositol formation in response to melatonin in cells labeled with $\left[{ }^{3} \mathrm{H}\right]$ myoinositol. As expected from the activation of $\mathrm{G}_{\mathrm{q}}$, incubation of muscle cells with melatonin for $60 \mathrm{~s}$ caused an increased in inositol formation in a concentrationdependent fashion with an $\mathrm{IC}_{50}$ of $4 \pm 1 \mathrm{nM}$ (Fig. 3A). The increase was significant at $0.1 \mathrm{nM}$ $(1473 \pm 104 \mathrm{cpm} / \mathrm{mg}$ protein above basal levels of $896 \pm 101 \mathrm{cpm} / \mathrm{mg}$ protein, $\mathrm{p}<0.01, \mathrm{n}=4)$ and a maximal increase was obtained at $1 \mu \mathrm{M}(7142 \pm 351 \mathrm{cpm} / \mathrm{mg}$ protein/mg protein above basal levels, $p<0.001, n=4)$. The extent of stimulation of PLC- $\beta$ activity with melatonin was similar to that obtained with other contractile agonists such as acetylcholine or substance $\mathrm{P}$ in gastric smooth muscle cells.

Activation of PLC- $\beta$ results in the generation of inositol 1, 4, 5-trisphosphate $\left(\mathrm{IP}_{3}\right)$ and $\mathrm{IP}_{3^{-}}$ dependent $\mathrm{Ca}^{2+}$ release from intracellular sarcoplasmic reticulum stores [34]. Consistent with the activation of $\mathrm{G}_{\mathrm{q}}$ and stimulation of PLC- $\beta$ activity, addition of melatonin to cells loaded with fura- 2 resulted in an increase in cytosolic $\mathrm{Ca}^{2+}$. The increase in $\mathrm{Ca}^{2+}$ was not affected by removal of extracellular $\mathrm{Ca}^{2+}$ suggesting that the increase is due to release of $\mathrm{Ca}^{2+}$ from intracellular stores (Fig. 3B).

The $\mathrm{G}$ protein involved in the activation of PLC- $\beta$ activity in response to melatonin was obtained by expression of $\mathrm{Ga}$ minigenes in cultured smooth muscle cells. The synthetic peptide corresponding to the $\mathrm{COOH}$ terminus of $\mathrm{Ga}$ subunits selectively antagonized $\mathrm{G}$ protein activation by blocking receptor-G protein interaction [25-29]. Minigene plasmid constructs that encode $\mathrm{COOH}$-terminal peptide sequence of $\mathrm{Ga}_{\mathrm{i}}$ and $\mathrm{Ga}_{\mathrm{q}}$ were expressed to selectively block $G_{i}$ and $G_{q}$ activation, respectively. Treatment of cultured muscle cells with melatonin $(1 \mu \mathrm{M})$ caused a significant increase in PLC- $\beta$ activity and the extent of stimulation was closely similar to that obtained in freshly dispersed smooth muscle cells $(5867 \pm 980 \mathrm{cpm} / \mathrm{mg}$ protein above basal levels in cultured smooth muscle cells and $6245 \pm 1005 \mathrm{cpm} / \mathrm{mg}$ protein above basal levels in freshly dispersed smooth muscle cells). Expression of $\mathrm{Ga}_{\mathrm{q}}$ minigene blocked stimulation of PI hydrolysis in response to melatonin. In contrast, expression of $\mathrm{Ga}_{\mathrm{i}}$ minigene had no effect on stimulation of PI hydrolysis PLC- $\beta$ activity (Fig. 4A) in response to melatonin. The results suggest that $\mathrm{MT}_{1}$ receptor coupled to activation of PLC- $\beta$ activity via $\mathrm{Ga}_{\mathrm{q}}$ and is consistent with the selective activation of $\mathrm{Ga}_{\mathrm{q}}$ by melatonin. The validity of Gi minigene approach to selectively block $\mathrm{G}$ proteindependent PLC- $\beta$ activity has been demonstrated in previous studies [28-30] and confirmed in the present study using cholecystokinin (CCK) and the cyclopentyladenosine (CPA). Previous studies in gastrointestinal smooth muscle have shown that CCK acts via Gqcoupled receptors to activate Gaq-dependent PLC- $\beta 1$, whereas CPA acts via Gi3-coupled A1 receptors to stimulate $\mathrm{G} \beta \gamma$-dependent PLC- $\beta 3$ [23, 35]. Expression of $\mathrm{Ga}_{\mathrm{q}}$ minigene also blocked stimulation of PI hydrolysis in response to CCK $(1 \mathrm{nM})$, whereas expression of $\mathrm{Ga}_{i}$ blocked stimulation of PI hydrolysis in response to (CPA, $\left.1 \mu \mathrm{M}\right)$ (Figs. 4B and 4C).

Stimulation of PLC- $\beta$ activity and increase in intracellular $\mathrm{Ca}^{2+}$ by contractile agonists in smooth muscle leads to muscle contraction. The functional significance of MT1 receptormediated stimulation of PLC- $\beta$ activity and increase in cytosolic $\mathrm{Ca}^{2+}$ was examined by measurements of muscle contraction by scanning micrometry. Contraction was measured as decrease in muscle cell length in response to melatonin compared to control cell length. Treatment of muscle cells with melatonin caused contraction in a concentration-dependent manner with a maximal contraction of $28 \pm 4 \%(\mathrm{p}<0.001, \mathrm{n}=6)$ decrease in cell length (basal cell length in the absence of melatonin treatment $125 \pm 4 \mu \mathrm{m}$ ) (Fig. 5). The extent of muscle contraction induced by melatonin is similar to that obtained with other contractile agonists such as acetylcholine, substance P, ATP, sphingosine 1-phosphate $(27 \pm 3 \%$ to $32 \pm 4 \%$ decrease in cell length) in smooth muscle cells. 
Melatonin-induced PI hydrolysis and muscle contraction were blocked by the selective PLC$\beta$ inhibitor, $\mathrm{U}-73122(10 \mu \mathrm{M})$ and by a non-selective $\mathrm{MT}_{1} / \mathrm{MT}_{2}$ receptor antagonist luzindole $(100 \mathrm{nM})$, but not by a selective $\mathrm{MT}_{2}$ receptor antagonist, 4P-PDOT $(100 \mathrm{nM})$. Consistent with this a selective $\mathrm{MT}_{2}$ receptor against IIK7 had no effect on PI hydrolysis or muscle contraction. Muscle contraction in response to melatonin was also inhibited a selective MLCK inhibitor ML-9 $(1 \mu \mathrm{M})(6 \pm 5 \%$ decrease in cell length) (Fig. 6). These results suggest that contraction in response to melatonin was mediated via activation $\mathrm{MT}_{1}$ receptors coupled to activation of PLC- $\beta$ via Ga $a_{q}$, generation of $\mathrm{IP}_{3}$ and $\mathrm{IP}_{3}$-dependent $\mathrm{Ca}^{2+}$ release, and stimulation of $\mathrm{Ca}^{2+} /$ calmodulin-dependent MLC kinase activity.

\section{Discussion}

Melatonin release from pineal gland displays a circadian rhythmic pattern with the increased release during nighttime and decreased release during the daytime [1]. Melatonin regulates rhythmic changes in gastrointestinal motility [6,7]. Several studies in isolated muscle strips demonstrated that the actions of melatonin are complex and involve both direct and indirect effects on smooth muscle including antagonistic relationship between serotonin and melatonin [8-10, 16-21]. Melatonin acting via $\mathrm{MT}_{1}$ and $\mathrm{MT}_{2}$ receptors is shown to activate various intracellular signaling pathways including inhibition of adenylyl cyclase and soluble guanylyl cylcase activity, and stimulation of PLC- $\beta$ activity [36]. The present study characterized the signaling pathways mediated by melatonin receptors in gastric smooth muscle cells using biochemical, molecular and functional methods. The results demonstrate the expression of $\mathrm{MT}_{1}$, but not $\mathrm{MT}_{2}$ receptors in gastric smooth muscle cells and their ability to stimulate PLC- $\beta$ activity via $\mathrm{Ga}_{\mathrm{q}}$, increase intracellular $\mathrm{Ca}^{2+}$ and induce smooth muscle contraction.

The evidence for the coupling of $\mathrm{MT}_{1}$ receptors to $\mathrm{G}_{\mathrm{q}}$-dependent stimulation of PLC- $\beta$ activity and to elicit muscle contraction was based on a combination of experimental strategies. (i) mRNA and protein expression of $\mathrm{MT}_{1}$ was demonstrated in cultured muscle cells by RT-PCR and in isolated muscle cells by western blot. $\mathrm{MT}_{2}$ receptors are not detected by RT-PCR or western blot analysis, raising the possibility that the expression of these proteins is either absent or not abundant in these cells. mRNA transcripts for all both $\mathrm{MT}_{1}$ and $\mathrm{MT}_{2}$ receptors have been detected in rat intestine [7, 18, 19]. Radioligand binding studies in the gastrointestinal (GI) tract of duck have identified regional differences in the densities with the following descending order of density: ileum > colon > esophagus [37]. Western blot analysis $\mathrm{MT}_{2}$ receptors in rat GI tract have demonstrated highest expression expression in colon [38]. These and other studies suggest that expression levels also vary with different regions and with species [39, 40]. However, cell-specific expression of $\mathrm{MT}_{1}$ and $\mathrm{MT}_{2}$ receptor in the GI is not clear. (ii) The $\mathrm{MT}_{1}$ receptors are coupled to activation of $\mathrm{G}_{\mathrm{q}}$. Selective activation of $\mathrm{G}_{\mathrm{q}}$ was demonstrated using $\left[{ }^{35} \mathrm{~S}\right] \mathrm{GTP} \gamma \mathrm{S}$ and subtype-selective $\mathrm{G}$ protein antibodies. $\left[{ }^{35} \mathrm{~S}\right] \mathrm{GTP} \gamma \mathrm{S}$.Ga complexes activated by melatonin bound selectively to $\mathrm{Ga}_{\mathrm{q}}$ antibodies reflecting activation of $\mathrm{G}_{\mathrm{q}}$ proteins. No melatonin induced increase in the binding to $\mathrm{Ga}_{\mathrm{i} 1}, \mathrm{Ga}_{\mathrm{i} 2}, \mathrm{Ga}_{\mathrm{i} 3}$, or $\mathrm{Ga}_{\mathrm{s}}$ antibodies to $\left[{ }^{35} \mathrm{~S}\right] \mathrm{GTP} \gamma \mathrm{S}$ could be detected. Studies in various cell lines suggest that $\mathrm{MT}_{1}$ are coupled to both PTx-sensitive and PTx-insensitive G proteins [36]. Our studies demonstrate that $\mathrm{MT}_{1}$ receptors are coupled to $P$ Tx-insensitive $\mathrm{G}_{\mathrm{q}}$ protein. (iii) Melatonin caused an increase in PLC- $\beta$ activity (PI hydrolysis) in a concentration-dependent fashion. The extent of increase was similar to that obtained with other $\mathrm{G}_{\mathrm{q}}$-coupled receptors in gastric smooth muscle cells [28-30]. Previous studies in these muscle cells have shown that receptors coupled to both $\mathrm{G}_{\mathrm{q}}$ and $\mathrm{G}_{\mathrm{i}}$ proteins stimulate PI hydrolysis via distinct PLC- $\beta$ isoforms $[23,28-30,34] . \mathrm{G}_{\mathrm{q}}$ coupled receptors such as muscarinic $\mathrm{m} 3$, sphingosine-1-phosphate $2\left(\mathrm{~S}_{1} \mathrm{P}_{2}\right)$, endothelin $\mathrm{ET}_{\mathrm{A}}$, purinergic $\mathrm{P} 2 \mathrm{Y} 2$, and NPY2 are coupled to stimulation of PI hydrolysis via $\mathrm{Ga}_{\mathrm{q}}$-dependent PLC- $\beta 1$ isozyme, whereas $G_{i 3}$ - adenosine $A_{1}$ receptors are coupled to stimulation of PI hydrolysis via G $\beta \gamma i$ - 
dependent PLC- $\beta 3$ isozyme [28-30, 34, 35]. The specific G proteins involved in the stimulation of PLC- $\beta$ activity by melatonin was examined using the minigene approach. Previous studies have shown that the $\mathrm{COOH}$-terminus of $\mathrm{G}$ protein a subunits is critical in mediating receptor- $\mathrm{G}$ protein interaction and peptides corresponding to $\mathrm{COOH}$-terminus serve as competitive inhibitors of receptor-G protein interaction [25-29]. The minigene plasmid vectors were designed to express the $\mathrm{COOH}$-terminal peptide sequences of various Ga subunits after transfection into cells. In gastric muscle cells transfection of minigene plasmid constructs that encode oligonucleotide sequences corresponding to $\mathrm{Ga}_{\mathrm{q}}$ completely blocked the activation of PLC- $\beta$ activity by melatonin. The results provide evidence that $\mathrm{MT}_{1}$ receptors are coupled to stimulation of PLC- $\beta$ activity via $\mathrm{G}_{\mathrm{q}}$ and this is consistent with the selective activation of $\mathrm{G}_{\mathrm{q}}$. (iv) Melatonin, as other Gq-coupled receptors, induced an increase in intracellular $\mathrm{Ca}^{2+}$ in single muscle cells. The increase in $\mathrm{Ca}^{2+}$ was not affected by removal of extracellular $\mathrm{Ca}^{2+}$ suggesting that the source of $\mathrm{Ca}^{2+}$ was intracellular. This is consistent with the activation of PLC- $\beta$ activity which results in the generation of $\mathrm{Ca}^{2+}$ mobilizing messenger $\mathrm{IP}_{3}$. The increase $\mathrm{Ca}^{2+}$ and the binding of $\mathrm{Ca}^{2+}$ to calmodulin results in the stimulation of $\mathrm{Ca}^{2+} /$ calmodulin-dependent myosin light chain (MLC) kinase activity and phosphorylation of $\mathrm{MLC}_{20}$ at $\mathrm{Ser}^{19}$, a prerequisite for initiation of actomyosin interaction and muscle contraction [34]. (v) Consistent with the stimulation of PLC- $\beta$ activity and increase in intracellular $\mathrm{Ca}^{2+}$ in response to melatonin, addition of melatonin to dispersed gastric muscle cells elicited rapid (30 s) muscle contraction. Contraction was blocked by the inhibitors of PLC- $\beta$ or MLC kinase. The extent of muscle contraction was similar to the other contractile agonists such as acetylcholine and substance $\mathrm{P}$ [28-30]. (vi) PI hydrolysis and muscle contraction were blocked by a non-selective $\mathrm{MT}_{1}$ / $\mathrm{MT}_{2}$ receptor antagonist, whereas a selective $\mathrm{MT}_{2}$ agonist did not stimulate PI hydrolysis or muscle contraction and a selective $\mathrm{MT}_{2}$ receptor antagonist had no effect on PI hydrolysis and muscle contraction in response to melatonin.

From a physiological point of view, melatonin produced in the enterochromaffin cells or by pineal gland act on myenteric neurons and smooth muscle cells to regulate gut motility [2]. Both contraction and relaxation of smooth muscle have been reported in previous studies [16-22]. In vivo effects of melatonin also depend on the dose of melatonin with small doses accelerating intestinal transit and high doses inhibiting the transit [16]. In vitro spontaneous and serotonin-induced contractions of rat duodenum are inhibited by high doses of melatonin [21]. The mechanism by which melatonin regulates motility is not clear and some studies suggested blockade of nicotinic channels and interaction with $\mathrm{Ca}^{2+}$ activated $\mathrm{K}^{+}$ channels [18]. Studies by Lucchelli et al [21] demonstrated direct contractile effect of melatonin in gastrointestinal smooth muscle. These studies demonstrated that melatonin and its analogues induced contractile responses in guinea pig proximal colon in a concentrationdependent manner. The rank of agonist potency was: 2 -indomelatonin $>6-$ chloromelatonin $>\mathrm{N}$-acetyl-5-HT>5-MCA-NAT>melatonin, an order typical for $\mathrm{MT}_{2}$ receptors. However, prazosin, an a-adrenoreceptor antagonist possessing moderate/high affinity for melatonin $\mathrm{MT}_{2}$ sites had no effect on melatonin-induced contractions. While the rank order of agonist potencies would suggest the participation of $\mathrm{MT}_{2}$ receptors, the ineffectiveness of prazosin on melatonin-induced contractions suggests the contrary. In contrast to contractile effect, studies by Storr et al [19] have demonstrated that addition of melatonin to isolated gastric and intestine muscle strips caused inhibition of NANCmediated muscle relaxation via $\mathrm{MT}_{1}$ receptors. These studies suggest that the effect of melatonin may vary in different species and different regions of the gut depending on whether the activated receptor is present predominantly on smooth muscle cells or enteric neurons. Our studies provide evidence for the involvement of $\mathrm{MT}_{1}$ receptors in melatonininduced contraction in isolated muscle cell devoid of neural elements. 
In summary, the present study demonstrated that gastric smooth muscle cells express receptors $\left(\mathrm{MT}_{1}\right)$ for melatonin preferentially coupled to $\mathrm{G}_{\mathrm{q}}$. Activation of these receptors by melatonin causes stimulation of PLC- $\beta$ activity and $\mathrm{Ca}^{2+}$ release from intracellular stores resulting in muscle contraction (Fig. 7).

\section{Acknowledgments}

This work was supported by National Institute of Diabetes and Digestive and Kidney Diseases Grants (DK28300 and DK15564 to KS Murthy and DK 34153 to JR Grider). We thank Dr. Lyall and S. Mummalaneni for their expert technical help with the $\mathrm{Ca}^{2+}$ measurements in single muscle cells.

\section{References}

1. Zawilska JB, Skene DJ, Arendt J. Physiology and pharmacology of melatonin in relation to biological rhythms. Pharmacol Rep. 2009; 61:383-410. [PubMed: 19605939]

2. Raikhlin NT, Kvetnoy IM. Melatonin and enterochromaffine cells. Acta Histochem. 1976; 55:1924. [PubMed: 818867]

3. Raikhlin NT, Kvetnoy IM, Tolkachev VN. Melatonin may be synthesised in enterochromaffin cells. Nature. 1975; 255:344-345. [PubMed: 1128697]

4. Kvetnoy IM, Ingel IE, Kvetnaia TV, Malinovskaya NK, Rapoport SI, Raikhlin NT, Trofimov AV, Yuzhakov VV. Gastrointestinal melatonin: cellular identification and biological role. Neuro Endocrinol Lett. 2002; 23:121-132. [PubMed: 12011798]

5. Bubenik GA, Hacker RR, Brown GM, Bartos L. Melatonin concentrations in the luminal fluid, mucosa, and muscularis of the bovine and porcine gastrointestinal tract. J Pineal Res. 1999; 26:5663. [PubMed: 10102761]

6. Lee PP, Pang SF. Melatonin and its receptors in the gastrointestinal tract. Biol Signals. 1993; 2:181193. [PubMed: 8205161]

7. Chen CQ, Fichna J, Bashashati M, Li YY, Storr M. Distribution, function and physiological role of melatonin in the lower gut. World J Gastroenterol. 2007; 17:3888-3898. [PubMed: 22025877]

8. Thor PJ, Krolczyk G, Gil K, Zurowski D, Nowak L. Melatonin and serotonin effects on gastrointestinal motility. J Physiol Pharmacol. 2007; 58(6):97-103. [PubMed: 18212403]

9. Teresa Martin M, Azpiroz F, Malagelada JR. Melatonin as a modulator of the ileal brake mechanism. Scand J Gastroenterol. 2005; 40:559-563. [PubMed: 16036508]

10. Martin MT, Azpiroz F, Malagelada JR. Melatonin and the gastrointestinal tract. Therapie. 1998; 53:453-458. [PubMed: 9921037]

11. Reppert SM. Melatonin receptors: molecular biology of a new family of G protein-coupled receptors. J Biol Rhythms. 1997; 12:528-531. [PubMed: 9406026]

12. Reppert SM, Godson C, Mahle CD, Weaver DR, Slaugenhaupt SA, Gusella JF. Molecular characterization of a second melatonin receptor expressed in human retina and brain: the Mel1b melatonin receptor. Proc Natl Acad Sci U S A. 1995; 92:8734-8738. [PubMed: 7568007]

13. Reppert SM, Weaver DR, Ebisawa T. Cloning and characterization of a mammalian melatonin receptor that mediates reproductive and circadian responses. Neuron. 1994; 13:1177-1185. [PubMed: 7946354]

14. Dubocovich ML, Markowska M. Functional MT1 and MT2 melatonin receptors in mammals. Endocrine. 2005; 27:101-110. [PubMed: 16217123]

15. von Gall C, Stehle JH, Weaver DR. Mammalian melatonin receptors: molecular biology and signal transduction. Cell Tissue Res. 2002; 309:151-162. [PubMed: 12111545]

16. Drago F, Macauda S, Salehi S. Small doses of melatonin increase intestinal motility in rats. Dig Dis Sci. 2002; 47:1969-1974. [PubMed: 12353839]

17. Kasimay O, Cakir B, Devseren E, Yegen BC. Exogenous melatonin delays gastric emptying rate in rats: role of CCK2 and 5-HT3 receptors. J Physiol Pharmacol. 2005; 56:543-553. [PubMed: 16391413] 
18. Storr M, Schusdziarra V, Allescher HD. Inhibition of small conductance K+ -channels attenuated melatonin-induced relaxation of serotonin-contracted rat gastric fundus. Can J Physiol Pharmacol. 2000; 78:799-806. [PubMed: 11077980]

19. Storr M, Koppitz P, Sibaev A, Saur D, Kurjak M, Franck H, Schusdziarra V, Allescher HD. Melatonin reduces non-adrenergic, non-cholinergic relaxant neurotransmission by inhibition of nitric oxide synthase activity in the gastrointestinal tract of rodents in vitro. J Pineal Res. 2002; 33:101-108. [PubMed: 12153444]

20. Merle A, Delagrange P, Renard P, Lesieur D, Cuber JC, Roche M, Pellissier S. Effect of melatonin on motility pattern of small intestine in rats and its inhibition by melatonin receptor antagonist $\mathrm{S}$ 22153. J Pineal Res. 2000; 29:116-124. [PubMed: 10981825]

21. Lucchelli A, Santagostino-Barbone MG, Tonini M. Investigation into the contractile response of melatonin in the guinea-pig isolated proximal colon: the role of 5-HT4 and melatonin receptors. $\mathrm{Br}$ J Pharmacol. 1997; 121:1775-1781. [PubMed: 9283717]

22. Murthy KS, Makhlouf GM. Phosphoinositide metabolism in intestinal smooth muscle: preferential production of $\mathrm{IP}_{3}$ in circular muscle cells. Am J Physiol. 1991; 261:G945-951. [PubMed: 1662916]

23. Murthy KS, Makhlouf GM. Functional characterization of phosphoinositide-specific phospholipase C-beta1 and beta 3 in intestinal smooth muscle. Am J Physiol. 1995; 269:C969-78. [PubMed: 7485467]

24. Teng B, Murthy KS, Kuemmerle JF, Grider JR, Sase K, Michel T, Makhlouf GM. Expression of endothelial nitric oxide synthase in human and rabbit gastrointestinal smooth muscle cells. Am J Physiol. 1998; 275:G342-351. [PubMed: 9688662]

25. Gilchrist A, Li A, Hamm HE. Design and use of C-terminal minigene vectors for studying role of heterotrimeric G proteins. Methods Enzymol. 2002; 344:58-69. [PubMed: 11771412]

26. Gilchrist A, Vanhauwe JF, Li A, Thomas TO, Voyno-Yasenetskaya T, Hamm HE. G alpha minigenes expressing C-terminal peptides serve as specific inhibitors of thrombin-mediated endothelial activation. J Biol Chem. 2001; 276:25672-25679. [PubMed: 11274183]

27. Gilchrist A, Bunemann M, Li A, Hosey MM, Hamm HE. A dominant-negative strategy for studying roles of $\mathrm{G}$ proteins in vivo. J Biol Chem. 1999; 274:6610-6616. [PubMed: 10037756]

28. Zhou H, Murthy KS. Distinctive G protein-dependent signaling in smooth muscle by sphingosine 1-phosphate receptors S1P1 and S1P2. Am J Physiol Cell Physiol. 2004; 286:C1130-1138. [PubMed: 15075212]

29. Sriwai W, Zhou H, Murthy KS. G(q)-dependent signalling by the lysophosphatidic acid receptor LPA(3) in gastric smooth muscle: reciprocal regulation of MYPT1 phosphorylation by Rho kinase and cAMP-independent PKA. Biochem J. 2008; 411:543-551. [PubMed: 18237278]

30. Huang J, Zhou H, Mahavadi S, Sriwai W, Lyall V, Murthy KS. Signaling pathways mediated gastrointestinal smooth muscle contraction and MLC20 phosphorylation by motilin receptors. Am J Physiol. 2005; 288:G23-31.

31. Ting KN, Blaylock NA, Sugden D, Delagrange P, Scalbert E, Wilson VG. Molecular and pharmacological evidence for MT1 melatonin receptor subtype in the tail artery of juvenile Wistar rats. Br J Pharmacol. 1999; 127:987-995. [PubMed: 10433507]

32. Fisher SP, Sugden D. Sleep-promoting action of IIK7, a selective MT2 melatonin receptor agonist in the rat. Neurosci Lett. 2009; 457:93-96. [PubMed: 19429170]

33. Dortch-Carnes J, Tosini G. Melatonin receptor agonist-induced reduction of SNP-released nitric oxide and cGMP production in isolated human non-pigmented ciliary epithelial cells. Exp Eye Res. 2012; 107:1-10. [PubMed: 23201027]

34. Murthy KS. Signaling for contraction and relaxation in smooth muscle of the gut. Annu Rev Physiol. 2006; 68:345-374. [PubMed: 16460276]

35. Murthy KS, Makhlouf GM. Adenosine A1 receptor-mediated activation of phospholipase C-beta 3 in intestinal muscle:dual requirement for alpha and beta gamma subunits of Gi3. Mol Pharmacol. 1995; 47:1172-1179. [PubMed: 7603457]

36. Dubocovich ML, Delagrange P, Krause DN, Sugden D, Cardinali DP, Olcese J. International Union of Basic and Clinical Pharmacology. LXXV. Nomenclature, classification, and 
pharmacology of G protein-coupled melatonin receptors. Pharmacol Rev. 2010; 62:343-380. [PubMed: 20605968]

37. Lee PP, Shiu SY, Chow PH, Pang SF. Regional and diurnal studies of melatonin and melatonin binding sites in the duck gastro-intestinal tract. Biol Signals. 1995; 4:212-224. [PubMed: 8720688]

38. Stebelova K, Anttila K, Manttari S, Saarela S, Zeman M. Immunohistochemical definition of MT(2) receptors and melatonin in the gastrointestinal tissues of rat. Acta Histochem. 2010; 112:26-33. [PubMed: 19004484]

39. Poon AM, Mak AS, Luk HT. Melatonin and 2[125I]iodomelatonin binding sites in the human colon. Endocr Res. 1996; 22:77-94. [PubMed: 8690008]

40. Pontoire C, Bernard M, Silvain C, Collin JP, Voisin P. Characterization of melatonin binding sites in chicken and human intestines. Eur J Pharmacol. 1993; 247:111-118. [PubMed: 8281999] 


\section{Highlights}

- Gastric smooth muscle, cells express $\mathrm{MT}_{1}$ receptors for melatonin

- $\mathrm{MT}_{1}$ receptors are coupled to $\mathrm{G}_{\mathrm{q}} / \mathrm{PLC}-\beta 1 / \mathrm{IP}_{3} / \mathrm{Ca}^{2+}$ pathway and muscle contraction

- Signaling by $\mathrm{MT}_{1}$ receptors revealed a mechanism for regulation of gut motility 
A

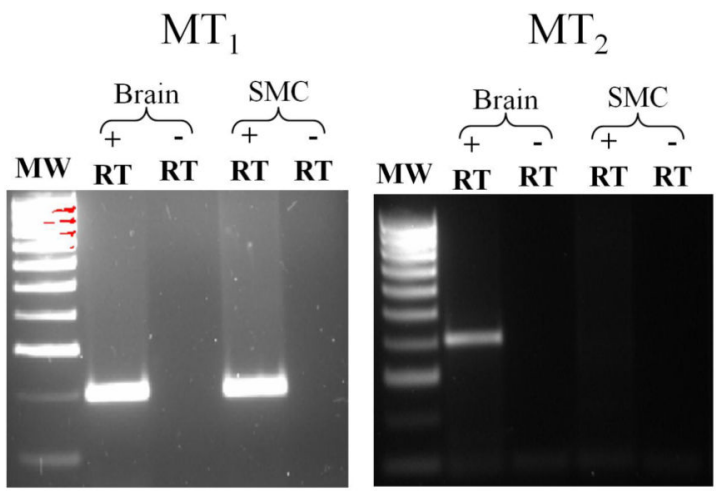

B

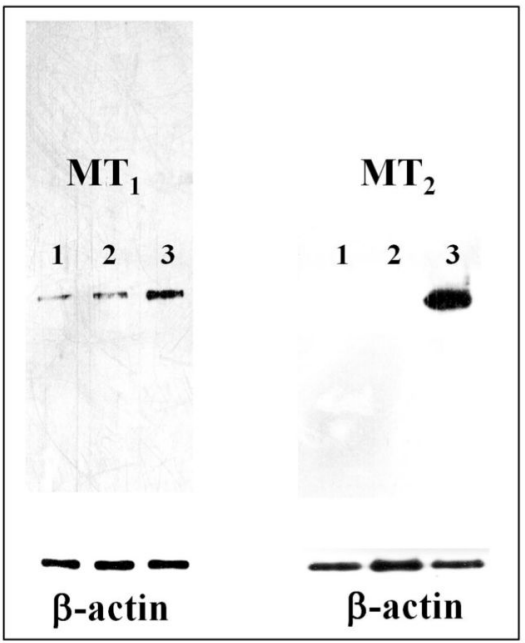

Figure 1. Expression of MT1 receptors and activation of $\mathrm{Ga}_{\mathrm{q}}$ by melatonin in gastric smooth muscle cells

(A) RT-PCR. Total RNA isolated from cultured (first passage) rabbit gastric muscle cells and the brain was reverse transcribed, and cDNA was amplified with specific primers for $\mathrm{MT}_{1}$ or $\mathrm{MT}_{2}$. Experiments were done in the presence (+ RT) or absence (-RT) of reverse transcriptase (RT). PCR product with predicted size was obtained in the presence of reverse transcriptase with primers for $\mathrm{MT}_{1}$ (194 bp), but not with primers for $\mathrm{MT}_{2}$, in smooth muscle cells (SMC), whereas PCR products were obtained with primers for $\mathrm{MT}_{1}$ (194 bp) and $\mathrm{MT}_{2}$ (392 bp) in the brain. (B) Western blot. Lysates prepared from dispersed smooth muscle cells (lane 1), cultured gastric smooth muscle cells (lane 2), and the brain (lane 3) of rabbit were run on SDS-PAGE and analyzed by western blot. Proteins were probed with polyclonal antibodies to $\mathrm{MT}_{1}(1: 1000)$ or $\mathrm{MT}_{2}$ (1:1000). A protein band corresponding to 40 $\mathrm{kDa}$ was obtained with only $\mathrm{MT}_{1}$ antibody in smooth muscle cells, whereas a protein bands corresponding to $40 \mathrm{kDa}$ were obtained with $\mathrm{MT}_{1}$ and $\mathrm{MT}_{2}$ antibody in the brain. 


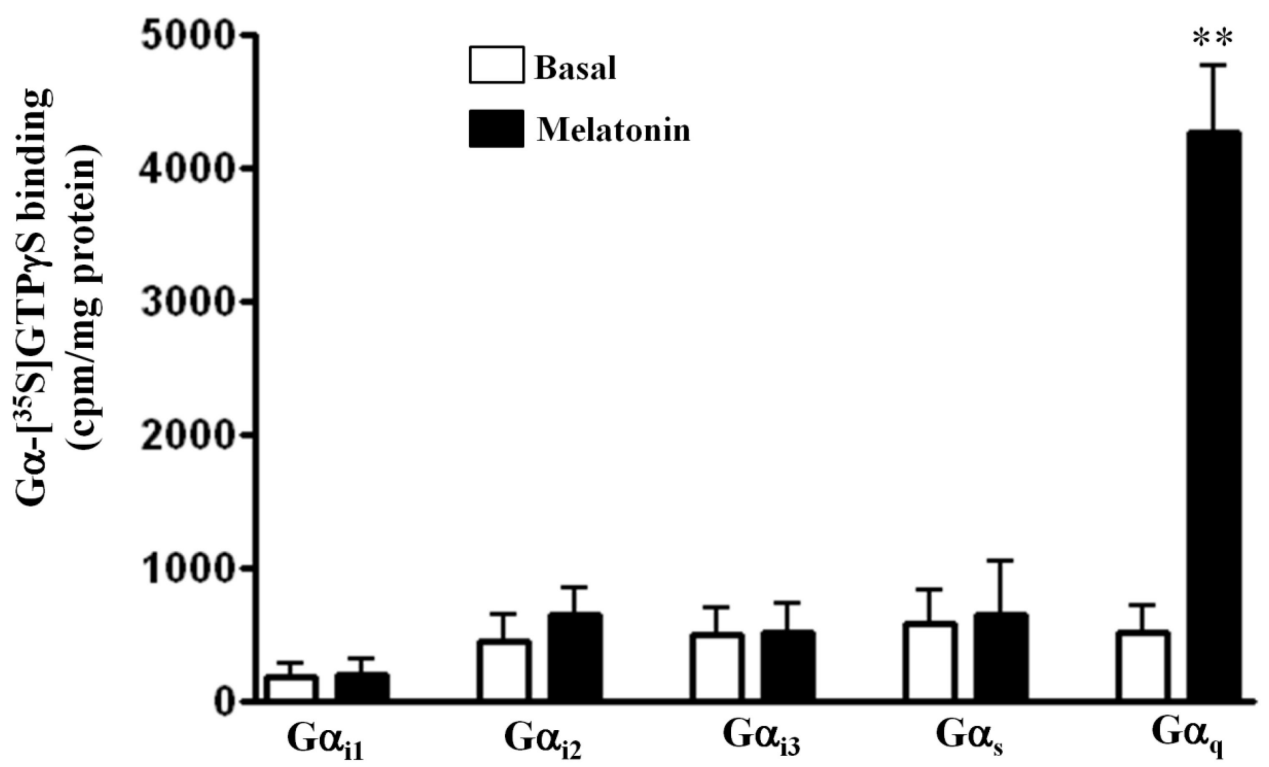

Figure 2. Selective activation of $\mathbf{G}_{\mathbf{q}}$ proteins by melatonin

Membranes were isolated from dispersed gastric muscle cells and incubated with $\left[{ }^{35} \mathrm{~S}\right] \mathrm{GTP} \gamma \mathrm{S}$ for $20 \mathrm{~min}$ in the presence or absence of melatonin $(1 \mu \mathrm{M})$. Aliquots were added to wells coated with antibody to $\mathrm{Ga}_{\mathrm{i} 2}, \mathrm{Ga}_{\mathrm{i} 3}, \mathrm{Ga}_{\mathrm{s}}$, or $\mathrm{Ga}_{\mathrm{q}}$ for $2 \mathrm{~h}$ and bound radioactivity from each well was counted by liquid scintillation. The amount of $\left[{ }^{35} \mathrm{~S}\right] \mathrm{GTP} \gamma \mathrm{S}$ bound to the activated $\mathrm{Ga}$ subunit was expressed as counts per minute (cpm) per milligram of protein. Melatonin induced significant increase in the binding of [ $\left.{ }^{35} \mathrm{~S}\right] \mathrm{GTP} \gamma \mathrm{S} . \mathrm{Ga}$ complexes to wells coated with $\mathrm{Ga}_{\mathrm{q}}$ antibody only. Values are mean \pm SEM of 4 experiments. ${ }^{*} \mathrm{p}<0.001$ significant increase in $\mathrm{Ga}_{\mathrm{q}}-\left[{ }^{35} \mathrm{~S}\right] \mathrm{GTP} \gamma \mathrm{S}$ binding in respone to melatonin. 

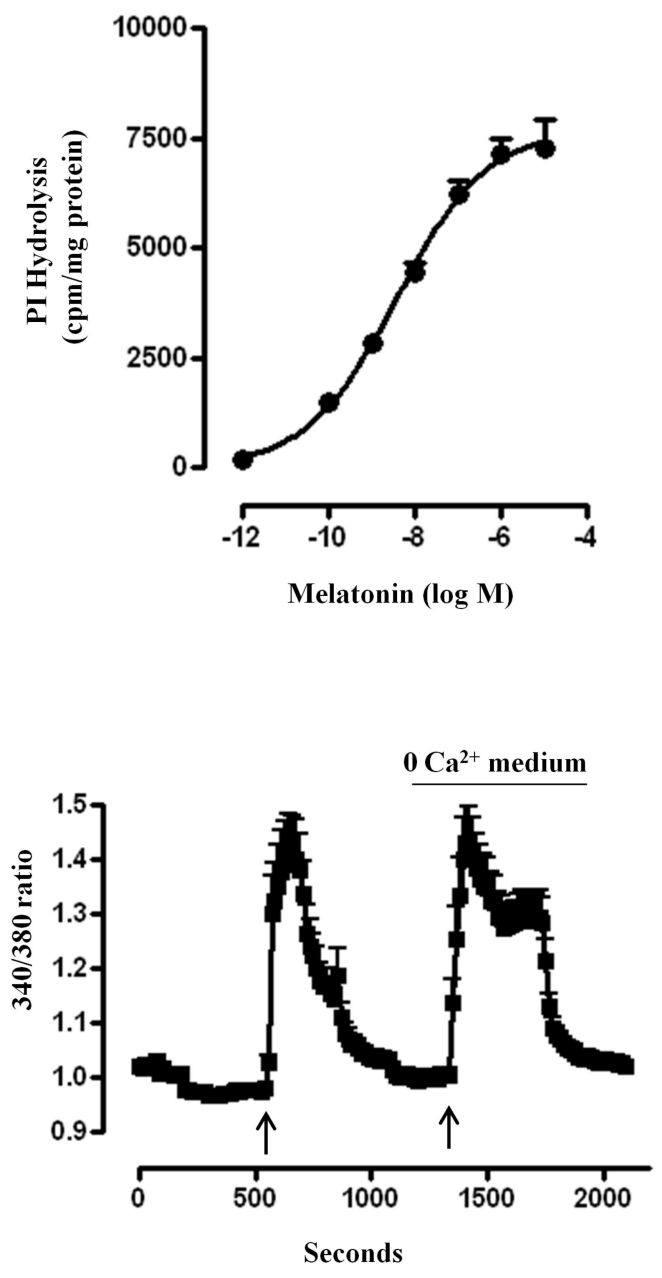

Figure 3. Stimulation of PLC- $\beta$ activity and release of $\mathrm{Ca}^{2+}$ by melatonin

(A) Phosphoinositide-specific (PI) hydrolysis (PLC- $\beta$ activity) in response to melatonin was measured in dispersed muscle cells labeled with myo- $\left[{ }^{3} \mathrm{H}\right]$ inositol. Freshly dispersed muscle cells were treated for $60 \mathrm{~s}$ with different concentrations of melatonin and PLC- $\beta$ activity was measured as increase in water-soluble $\left[{ }^{3} \mathrm{H}\right]$ inositol formation. The results are expressed as $\left[{ }^{3} \mathrm{H}\right]$ inositol phosphate formation in counts per minute $(\mathrm{cpm})$ per $\mathrm{mg}$ protein above basal levels (basal: $642 \pm 99 \mathrm{cpm} / \mathrm{mg}$ protein). Values are means \pm SEM of 4 experiments. (B) Isolated smooth cells were loaded with $5 \mu \mathrm{M}$ fura- 2 and treated with $1 \mu \mathrm{M}$ melatonin in the absence of extracellular $\mathrm{Ca}^{2+}$. The cells were alternately excited at $380 \mathrm{~nm}$ and $340 \mathrm{~nm}$. The background and autofluorescence were corrected from images of a cell without the fura 2 . Results are expressed as 340/380 ratio and an increase in ratio reflects an increase in cytosolic $\mathrm{Ca}^{2+}$. The figure shows results obtained from 38 cells. 

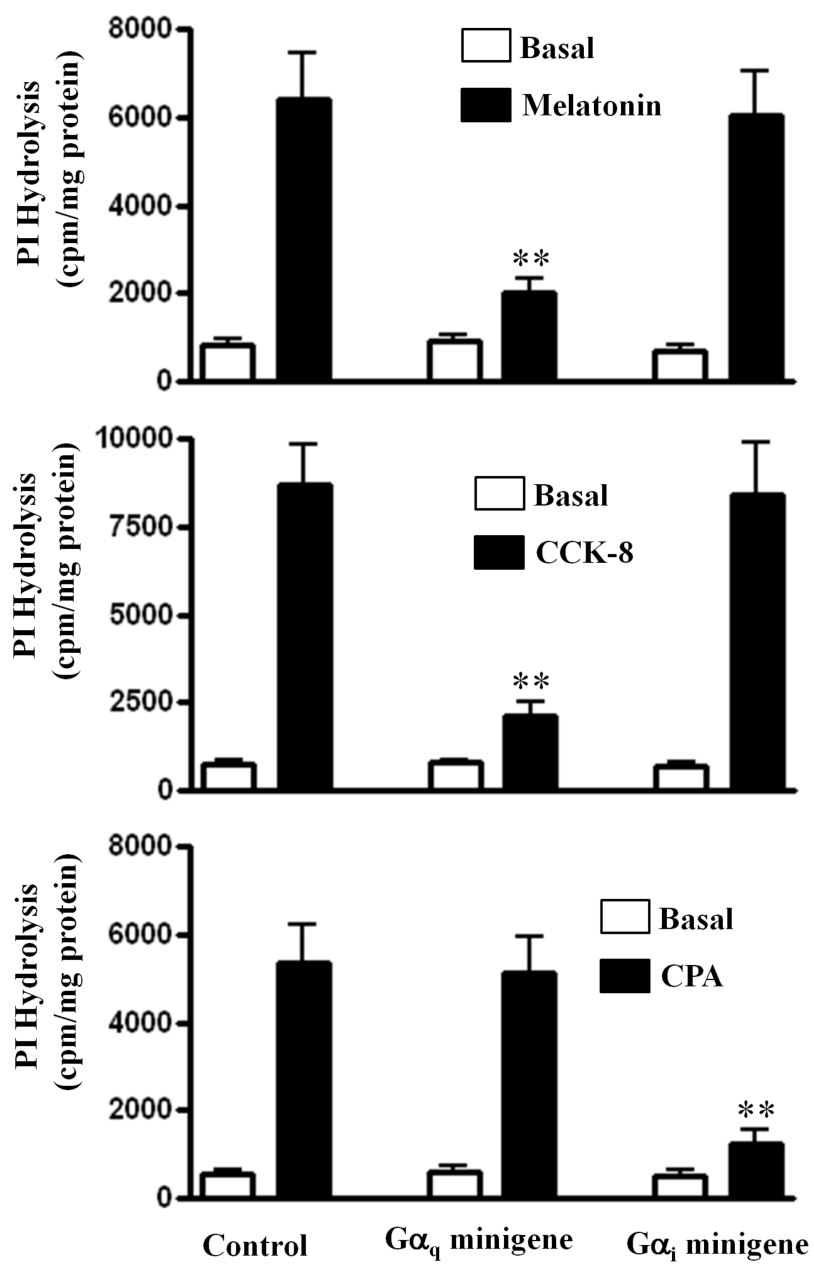

Figure 4. $\mathrm{Ga}_{\mathrm{q}}$-dependent activation of PI hydrolysis by melatonin

Cultured gastric muscle cells labeled with myo- $\left[{ }^{3} \mathrm{H}\right]$ inositol and expressing $\mathrm{Ga}_{\mathrm{q}}$ minigene, $\mathrm{Ga}_{\mathrm{i}}$ minigene, or control vector were treated with melatonin $(1 \mu \mathrm{M})$, cholecycstokinin $(\mathrm{CCk}, 1 \mathrm{~nm})$ or cyclopentyladenosine $(\mathrm{CPA}, 1 \mu \mathrm{M})$ for $60 \mathrm{~s}$. Total $\left[{ }^{3} \mathrm{H}\right]$ inositol phosphates were separated by ion-exchange chromatography. PI hydrolysis activity stimulated by melatonin or CCK was abolished in cells expressing $\mathrm{Ga}_{\mathrm{q}}$ minigene, but was not affected in cells expressing $\mathrm{Ga}_{\mathrm{i}}$ minigene. In contrast, PI hydrolysis activity stimulated by CPA was abolished in cells expressing $\mathrm{Ga}_{\mathrm{i}}$ minigene, but was not affected in cells expressing $\mathrm{Ga}_{\mathrm{q}}$ minigene. Results are expressed as total $\left[{ }^{3} \mathrm{H}\right]$ inositol phosphate formation in $\mathrm{cpm} / \mathrm{mg}$ protein. Values are means \pm SEM of four experiments. ** Significant inhibition from control response $(\mathrm{P}<0.01)$. 


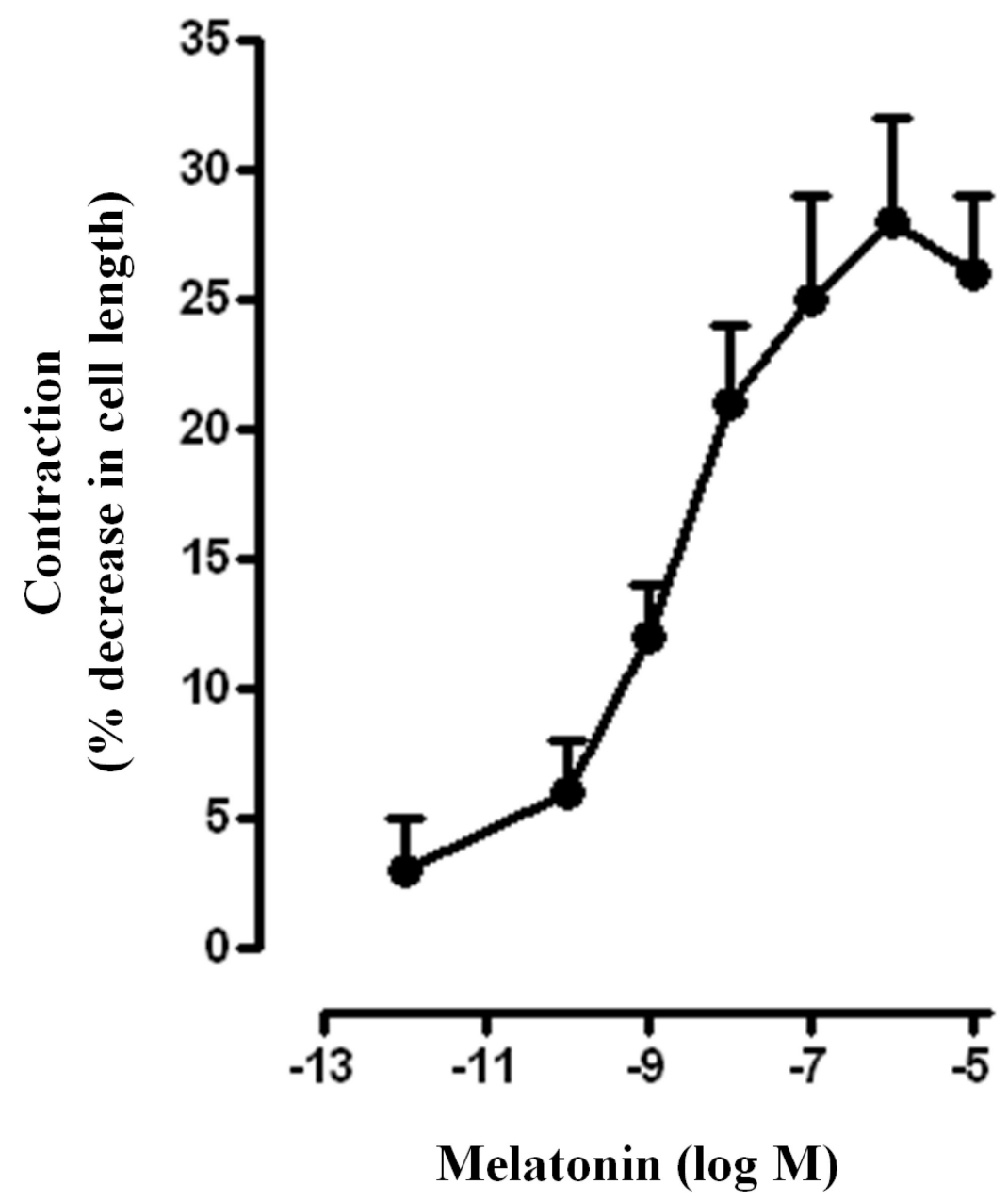

Figure 5. Stimulation of muscle contraction by melatonin

Contraction of muscle cells was measured as decrease in basal cell length in response to various concentrations of melatonin. Muscle cells $(0.5 \mathrm{ml}$ cell suspension $)$ were treated with melatonin for $30 \mathrm{~s}$ and the reaction was terminated with $0.1 \%$ acrolein. The mean length of 50 muscle cells was measured by scanning micrometry and was compared with the length of untreated muscle cells $(125 \pm 4 \mu \mathrm{m})$. The contractile response was expressed as the percent decrease in the mean cell length from control cell length. Values are means \pm SEM of 6 experiments. 

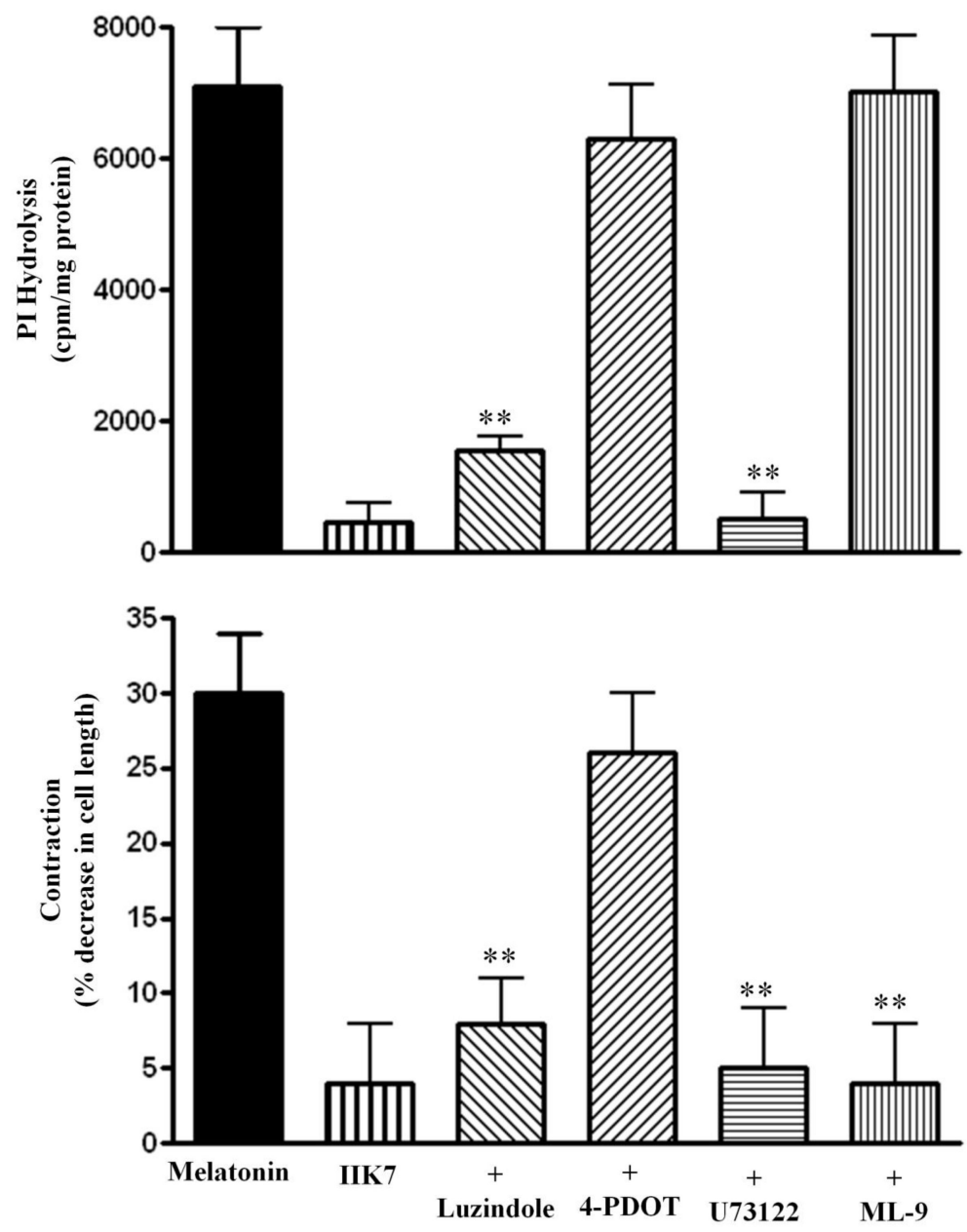

Figure 6. Stimulation PI hydrolysis and muscle contraction by melatonin via $\mathbf{M T}_{1}$ receptors (A) Phosphoinositide-specific (PI) hydrolysis (PLC- $\beta$ activity) was measured in dispersed muscle cells labeled with myo- $\left[{ }^{3} \mathrm{H}\right]$ inositol. Cells were treated for $60 \mathrm{~s}$ with melatonin in the presence or absence of a non-selective MT1/MT2 receptor antagonist luzindole (100 nM), a selective MT2 receptor antagonist 4P- PDOT (100 nM), PI hydrolysis inhibitor $(10 \mu \mathrm{M})$ or MLCK inhibitor ML-9 $(1 \mu \mathrm{M})$, or with a selective MT2 receptor agonist IIK7 alone (100 $\mathrm{nM})$. PLC- $\beta$ activity was measured as increase in water-soluble $\left[{ }^{3} \mathrm{H}\right]$ inositol formation. The results are expressed as $\left[{ }^{3} \mathrm{H}\right]$ inositol phosphate formation in counts per minute $(\mathrm{cpm})$ per $\mathrm{mg}$ protein above basal levels (basal: $562 \pm 102 \mathrm{cpm} / \mathrm{mg}$ protein). Values are means+SEM of 4 experiments. ** Significant inhibition from control melatonin response $(\mathrm{P}<0.01)$. (B) Dispersed muscle cells were treated for $30 \mathrm{~s}$ with melatonin in the presence or absence of luzindole $(100 \mathrm{nM})$, 4P-PDOT $(100 \mathrm{nM}),(10 \mu \mathrm{M})$, or MLCK inhibitor ML-9 $(1 \mu \mathrm{M})$, or with IIK7 alone (100 nM). Contraction of muscle cells was measured as decrease in basal cell length in response to various concentrations of melatonin. Muscle cells $(0.5 \mathrm{ml}$ cell suspension) were treated with melatonin $(1 \mu \mathrm{M})$ in the presence or absence of U73122 (10 $\mu \mathrm{M})$ or ML-9 $(1 \mu \mathrm{M})$. The mean length of 50 muscle cells was measured by scanning micrometry and was compared with the length of untreated muscle cells $(119 \pm 6 \mu \mathrm{m})$. The contractile response was expressed as the percent decrease in the mean cell length from control cell length. Values are means \pm SEM of 6 experiments. ** Significant inhibition from control melatonin response $(\mathrm{P}<0.01)$. 


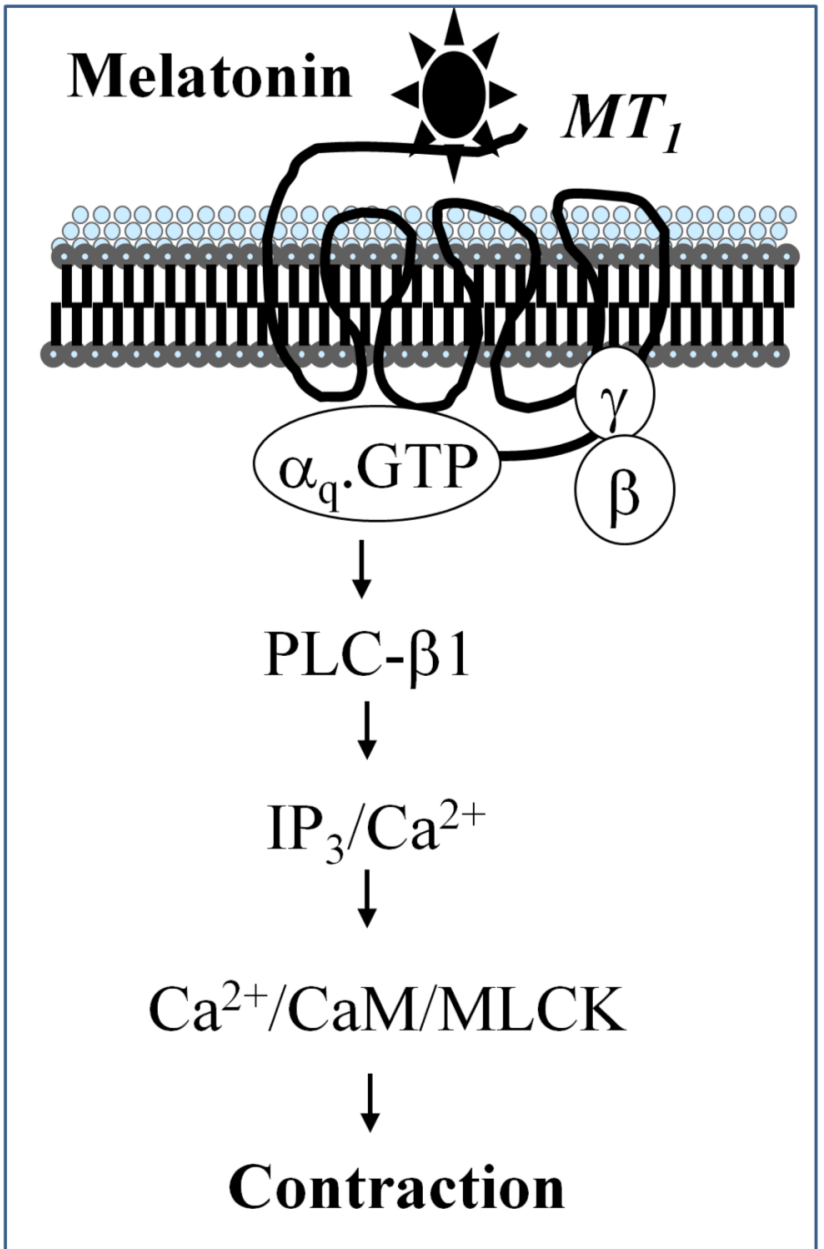

Figure 7. Pathway mediating muscle contraction by melatonin In gastric smooth muscle, melatonin interacts with MT1 receptors, which is coupled to stimulation of phosphoinositide-specific phospholipase C (PLC- $\beta$ ) via Gq. Stimulation of PLC- $\beta$ activity results in the generation of inositol 1,4,5-trisphosphate $\left(\mathrm{IP}_{3}\right)$ and $\mathrm{IP}_{3}$ dependent $\mathrm{Ca}^{2+}$ release leading to muscle contraction. 